\title{
Dietary supplemental vitamin B6 increases carnosine and anserine concentrations in the heart of rats
}

\author{
Sofya Suidasari, Tomoko Hasegawa, Noriyuki Yanaka and Norihisa Kato*
}

\begin{abstract}
This study was performed to examine the effect of dietary level of vitamin B6 on the concentrations of carnosine and anserine, antioxidants, in the heart of rats. Analysis using UPLC-MS/MS showed that the concentrations of these dipeptides in the 7 and $35 \mathrm{mg}$ pyridoxine $\mathrm{HCl} / \mathrm{kg}$ groups were significantly higher than those in the $1 \mathrm{mg}$ pyridoxine $\mathrm{HCl} / \mathrm{kg}$ group, implying the novel role of dietary vitamin B6 as a determinant of the dipeptides favorable for heart.
\end{abstract}

Keywords: Vitamin B6, Carnosine, Anserine, Heart, UPLC-MS/MS

\section{Background}

Increasing evidence indicates that lower levels of vitamin B6 (B6) are related to the risk of coronary heart disease and atherosclerosis (Robinson et al. 1998), with the antiinflammatory effect of B6 considered to be at least partially responsible for its protective effect against these diseases (Friso et al. 2004). Furthermore, B6 exerts an anti-ischemic effect in the heart by blocking purinergic receptors (Dhalla et al. 2013). However, the effect of B6 on the heart per se remains obscure.

Pyridoxal 5'-phosphate (PLP), the active form of B6, acts as a co-factor for several enzymes involved in amino acid metabolism. In this study, we hypothesized that dietary supplemental B6 affects heart dysfunction by modulating amino acid metabolism. Accordingly, we investigated the effects of low to high B6 diets on the concentrations of free amino acids and related metabolites in the heart of rats. Here we provide the first evidence that dietary supplemental B6 to a low B6 diet markedly elevates heart concentrations of carnosine and anserine, putative antioxidants favorable for heart (Boldyrev et al. 2013).

*Correspondence: nkato@hiroshima-u.ac.jp

Graduate School of Biosphere Science, Hiroshima University,

Higashi-Hiroshima 739-8528, Japan

\section{Methods}

Male Sprague-Dawley rats (4 weeks old, Charles River Japan, Hino, Japan) were maintained in accordance with the Guide for the Care and Use of Laboratory Animals established by Hiroshima University. The rats were housed in metal cages in a temperature-controlled room $\left(24 \pm 1^{\circ} \mathrm{C}\right)$ under a 12-h light/dark cycle (lights on, 0800-2000 hours). The rats had free access to food and deionized water. The basal diet was described previously (Masisi et al. 2012). Pyridoxine (PN) HCl was supplemented to the basal diet at concentrations of 1,7 , or $35 \mathrm{mg} / \mathrm{kg}$ diet. The $7 \mathrm{mg} / \mathrm{kg}$ diet is the recommended level of dietary B6 (Reeves et al. 1993). Meanwhile, $1 \mathrm{mg}$ $\mathrm{PN} \mathrm{HCl} / \mathrm{kg}$ diet is reported to be the minimum level required for preventing growth depression caused by B6 deficiency (Coburn 1994). After being fed a commercial non-purified diet (MF, Oriental Yeast, Tokyo, Japan) for 1 week, 24 rats (average body weight $70 \mathrm{~g}$ ) were randomly divided into three groups receiving 1,7 , or $35 \mathrm{mg}$ $\mathrm{PN} \mathrm{HCl} / \mathrm{kg}$ diet ( $n=8 /$ group) for 6 weeks. The animals were killed by decapitation under diethyl ether anesthesia. Serum was collected from truck blood and stored at $-60^{\circ} \mathrm{C}$. Hearts were quickly dissected, frozen in liquid nitrogen, and immediately stored at $-80^{\circ} \mathrm{C}$.

For analysis of carnosine and anserine in heart by ultra-performance liquid chromatography coupled with tandem mass spectrometry (UPLC-MS/MS), the frozen hearts were homogenized with cold $\left(4^{\circ} \mathrm{C}\right) 3 \%(\mathrm{w} / \mathrm{v})$

\section{Springer}


sulfosalicylic acid to precipitate protein. After centrifugation at $1,000 \times g$ at $4^{\circ} \mathrm{C}$ for $30 \mathrm{~min}$, the supernatants were collected and filtered through a $0.22-\mu \mathrm{m}$-pore membrane filter and immediately stored at $-80^{\circ} \mathrm{C}$ until analysis. The supernatant samples of each two rats from the same group of eight rats were combined to obtain the pooled four samples for the analysis. Separation was performed on an UPLC-MS/MS system as described previously (Waterval et al. 2009), with a slight modification. Analysis of PLP concentrations in the serum and heart was performed as described previously (Masisi et al. 2012). Serum samples were analyzed using a commercial carnosine ELISA kit (USCN Life Science, Inc., Wuhan, China). Data are expressed as mean \pm SE. Tukey's multiple-range test was used to compare means after one-way ANOVA. Statistical significance of the difference between means was estimated at $P<0.05$.

\section{Results and discussion}

Dietary manipulation did not affect food intake $(1,7$, and $35 \mathrm{mg} \mathrm{PN} \mathrm{HCl} / \mathrm{kg}$ groups: $731 \pm 10,787 \pm 15$, and
$772 \pm 24 \mathrm{~g} / 6$ weeks, respectively, $P>0.05)$ or final body weight (412 $\pm 9,444 \pm 9$, and $437 \pm 13 \mathrm{~g}$, respectively, $P>0.05)$. Heart weight in the 1,7 , and $35 \mathrm{mg} \mathrm{PN} \mathrm{HCl} / \mathrm{kg}$ groups were $1.14 \pm 0.05,1.20 \pm 0.03$, and $1.16 \pm 0.03 \mathrm{~g}$, respectively, $P>0.05)$. PLP concentrations in the heart and serum in the 7 and $35 \mathrm{mg} \mathrm{PN} \mathrm{HCl} / \mathrm{kg}$ groups were higher $(P<0.01)$ than those in the $1 \mathrm{mg} \mathrm{PN} \mathrm{HCl} / \mathrm{kg}$ group (Figures 1A, 2A, respectively). There was no significant difference in the PLP concentrations between the 7 and $35 \mathrm{mg} \mathrm{PN} \mathrm{HCl} / \mathrm{kg}$ groups.

Our preliminary study using the amino acid analyzer showed marked alterations in the concentrations of carnosine and anserine in the heart depending on the level of dietary B6. Thus, further analysis using UPLC-MS/MS was conducted to determine the concentrations of these dipeptides.

The 7 and $35 \mathrm{mg} \mathrm{PN} \mathrm{HCl} / \mathrm{kg}$ groups had markedly higher concentrations of carnosine $(+114$ and $+162 \%$, respectively, $P<0.01$, Figure $1 \mathrm{~B})$ and anserine $(+89$ and $+101 \%$, respectively, $P<0.01$, Figure $1 C$ ) than those in the $1 \mathrm{mg} \mathrm{PN} \mathrm{HCl} / \mathrm{kg}$ group. The concentrations of these
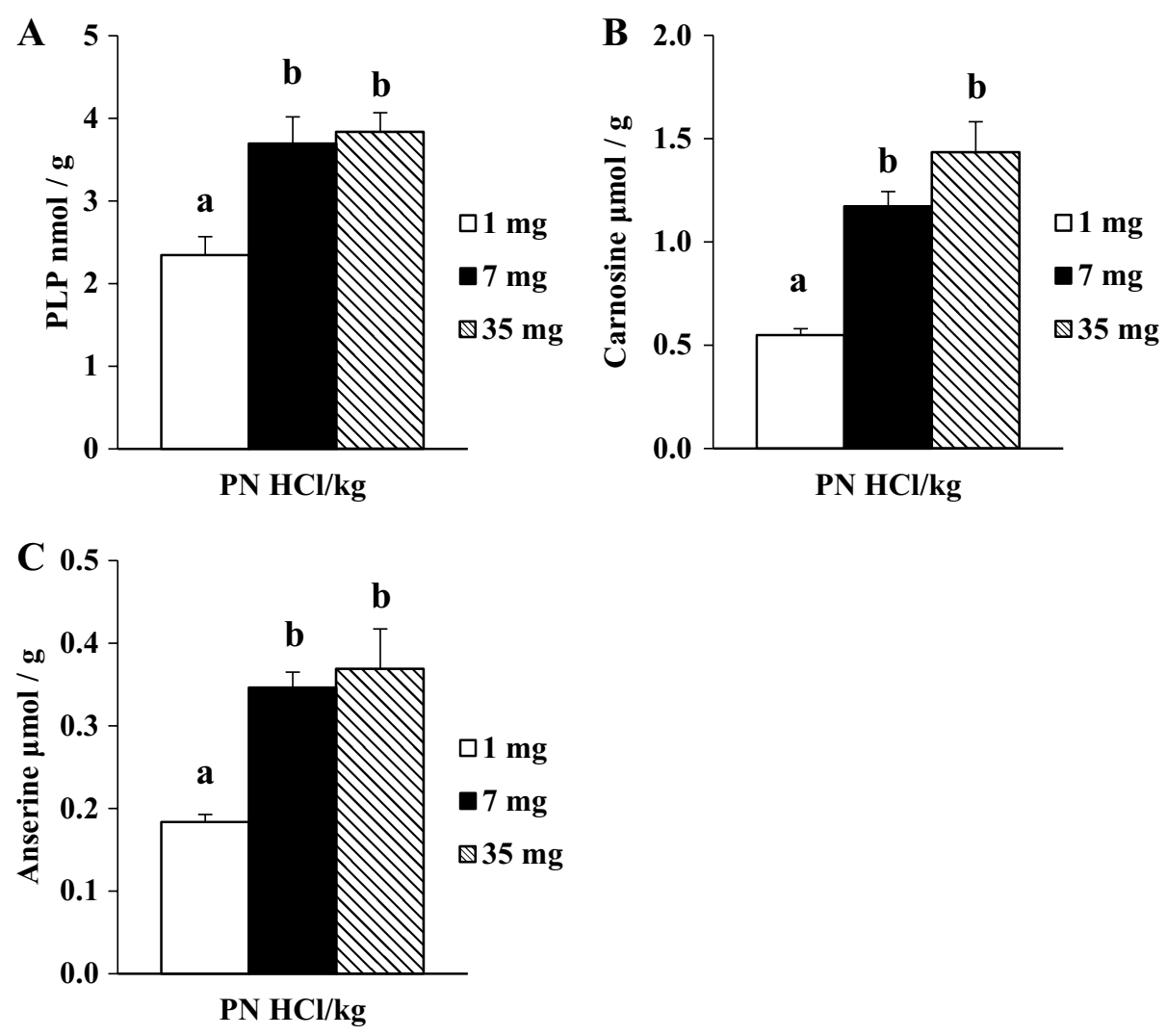

Figure 1 Effect of dietary levels of B6 (PN HCl) on concentrations of PLP (A), carnosine $(\mathbf{B})$, and anserine $(\mathbf{C})$ in the heart of rats. Mean \pm SE $(n=5$ for PLP; $n=4$ for carnosine and anserine). For the analysis of carnosine and anserine, the supernatant samples of each two rats from the same group of eight rats were combined to obtain the pooled four samples. Values with different superscript are significantly different by Tukey's multiplerange test $(P<0.05)$. 

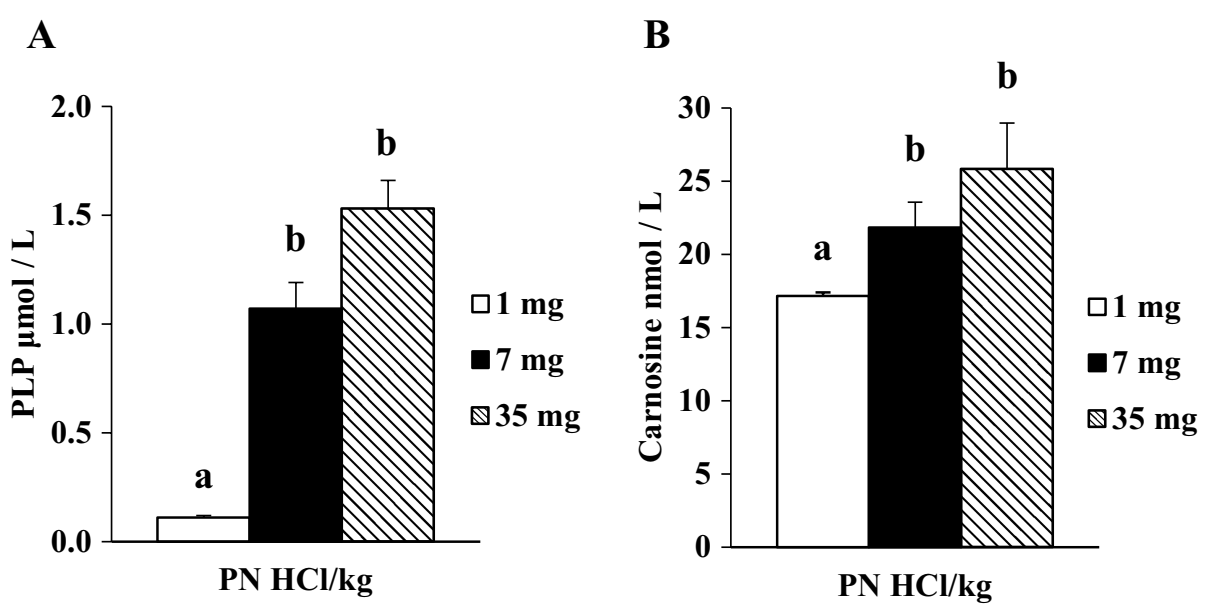

Figure 2 Effect of dietary levels of B6 (PN HCl) on concentrations of PLP $(\mathbf{A})$ and carnosine $(\mathbf{B})$ in the serum of rats. Mean \pm SE $(n=5$ for PLP; $n=8$ for carnosine). Values with different superscript are significantly different by Tukey's multiple-range test $(P<0.05)$.

peptides in the 7 and $35 \mathrm{mg} \mathrm{PN} \mathrm{HCl} / \mathrm{kg}$ groups did not differ. Carnosine is reported to exert anti-oxidant, antiinflammatory, and anti-ischemic effects on the heart (Boldyrev et al. 2013; Fleisher-Berkovich et al. 2009; Stvolinsky and Dobrota 2000). It has biochemical capacities such as $\mathrm{pH}$-buffering and metal ion chelation (Boldyrev et al. 2013). In cardiac myocytes, carnosine is suggested to be a modulator of intracellular calcium and contractility (Roberts and Zaloga 2000; Zaloga et al. 1997). Anserine also exerts anti-oxidant and anti-inflammatory effects (Song et al. 2014). Thus, the present results imply that dietary supplemental B6, correcting low B6 status, might be favorable for muscle function by elevating the histidyl-dipeptides.

B6 supplementation resulted in higher serum concentration of carnosine, with a significant difference between the $35 \mathrm{mg} \mathrm{PN} \mathrm{HCl} / \mathrm{kg}$ group and the $1 \mathrm{mg} \mathrm{PN} \mathrm{HCl} / \mathrm{kg}$ group $(P<0.05$, Figure $2 \mathrm{~B})$. It has been suggested that higher concentrations of carnosine on account of exercise decrease blood pressure in rats and humans (Nagai et al. 2012). A recent study suggested that plasma carnosine is involved in preventing early-stage lipid oxidation in circulation (Stegen et al. 2015). Thus, elevated serum carnosine following B6 supplementation may partially relate to the favorable effect of B6 on circulation. Nevertheless, further study is required to examine this possibility.

\section{Conclusion}

In conclusion, the present study indicated that inadequate level of $\mathrm{B} 6$ in the diet $(1 \mathrm{mg} \mathrm{PN} \mathrm{HCl} / \mathrm{kg}$ ) causes lower concentrations of heart carnosine and anserine, putative protective factors against heart dysfunction, compared to the recommended level of B6 and high level of $\mathrm{B} 6$ (7 and $35 \mathrm{mg} \mathrm{PN} \mathrm{HCl} / \mathrm{kg}$, respectively). Thus, adequate intake of B6 is likely to be necessary for maintaining the peptides in the heart. This finding is of importance because recent evidence suggests marginal B6 deficiency is common in the USA and Japan (Morris et al. 2008; Murakami et al. 2008). Further study is required to determine the underlying mechanisms by which B6 supplementation alters these dipeptides and thus exerts heart-protective effects.

\section{Abbreviations}

B6: vitamin B6; PLP: pyridoxal 5'-phosphate; PN: pyridoxine; UPLC-MS/ MS: ultra-performance liquid chromatography coupled with tandem mass spectrometry.

\section{Authors' contributions}

SS and NK designed the research; SS, TH and NY conducted the research; SS and TH analyzed the data; and SS and NK wrote the paper and had primary responsibility for the final content. All authors read and approved the final manuscript.

\section{Acknowledgements}

This study was supported in part by a Grant-in-Aid for Scientific Research from the Ministry of Education, Culture, Sports, Science and Technology of Japan.

\section{Compliance with ethical guidelines}

\section{Competing interest}

The authors declare that they have no competing interests.

Received: 6 May 2015 Accepted: 1 June 2015

Published online: 19 June 2015

\section{References}

Boldyrev AA, Aldini G, Derave W (2013) Physiology and pathophysiology of carnosine. Physiol Rev 93:1803-1845

Coburn SP (1994) A critical review of minimal vitamin B6 requirements for growth in various species with a proposed method of calculation. Vitam Horm 48:259-300 
Dhalla NS, Takeda S, Elimban V (2013) Mechanisms of the beneficial effects of vitamin B6 and pyridoxal 5-phosphate on cardiac performance in ischemic heart disease. Clin Chem Lab Med 51:535-543

Fleisher-Berkovich S, Abramovitch-Dahan C, Ben-Shabat S, Apte R, BeitYannai E (2009) Inhibitory effect of carnosine and $\mathrm{N}$-acetyl carnosine on LPS-induced microglial oxidative stress and inflammation. Peptides 7:1306-1312

Friso S, Girelli D, Martinelli N, Olivieri O, Lotto V, Bozzini C et al (2004) Low plasma vitamin B-6 concentrations and modulation of coronary artery disease risk. Am J Clin Nutr 79:992-998

Masisi K, Suidasari S, Zhang P, Okazaki Y, Yanaka N, Kato N (2012) Comparative study on the responses of concentrations of B6 vitamers in several tissues of mice to the dietary level of pyridoxine. J Nutr Sci Vitaminol 58:446-451

Morris MS, Picciano MF, Jacques PF, Selhub J (2008) Plasma pyridoxal 5'-phosphate in the US population: the National Health and Nutrition Examination Survey, 2003-2004. Am J Clin Nutr 87:1446-1454

Murakami K, Mizoue T, Sasaki S, Ohta M, Sato M, Matsushita Y et al (2008) Dietary intake of folate, other $B$ vitamins and $\omega-3$ polyunsaturated fatty acids in relation to depressive symptoms in Japan adults. Nutrition 24:140-147

Nagai K, Tanida M, Niijima A, Tsuruoka N, Kiso Y, Horii Y et al (2012) Role of L-carnosine in the control of blood glucose, blood pressure, thermogenesis, and lipolysis by autonomic nerves in rats: involvement of the circadian clock and histamine. Amino Acids 43:97-109

Reeves PG, Nielsen FH, Fahey GC Jr (1993) AIN-93 purified diets for laboratory rodents: final report of the American Institute of Nutrition ad hoc writing committee on the reformulation of the AIN-76A rodent diet. J Nutr 123:1939-1951

Roberts PR, Zaloga GP (2000) Cardiovascular effects of carnosine. Biochemistry (Mosc) 65:856-861

Robinson K, Arheart K, Refsum H, Brattström L, Boers G, Ueland P et al (1998) Low circulating folate and B6 concentrations: risk factors for stroke, peripheral vascular disease, and coronary artery disease. European COMAC Group. Circulation 97:437-443

Song BC, Joo NS, Aldini G, Yeum KJ (2014) Biological functions of histidinedipeptides and metabolic syndrome. Nutr Res Pract 8:3-10

Stegen S, Stegen B, Aldini G, Altomare A, Cannizzaro L, Orioli M et al (2015) Plasma carnosine, but not muscle carnosine, attenuates high-fat diet-induced metabolic stress. Appl Physiol Nutr Metab. doi:10.1139/ apnm-2015-0042

Stvolinsky SL, Dobrota D (2000) Anti-ischemic activity of carnosine. Biochemistry (Mosc) 65:849-855

Waterval WA, Scheijen JL, Ortmans-Ploemen MM, Habets-van der Poel CD, Bierau J (2009) Quantitative UPLC-MS/MS analysis of underivatised amino acids in body fluids is a reliable tool for the diagnosis and follow-up of patients with inborn errors of metabolism. Clin Chim Acta 407:36-42

Zaloga GP, Roberts PR, Black KW, Lin M, Zapata-Sudo G, Sudo RT et al (1997) Carnosine is a novel peptide modulator of intracellular calcium and contractility in cardiac cells. Am J Physiol 272:H462-H468

\section{Submit your manuscript to a SpringerOpen ${ }^{\odot}$ journal and benefit from:}

- Convenient online submission

- Rigorous peer review

- Immediate publication on acceptance

- Open access: articles freely available online

- High visibility within the field

- Retaining the copyright to your article

Submit your next manuscript at springeropen.com 